\section{Privatization for Japan}

\section{Tokyo}

JAPAN is about to take its first step towards privatizing its space industry. On 5 July, a huge private consortium will set up a company to mass-produce Japan's nextgeneration rocket, the H-II, from 1994.

Establishment of the new company comes close on the heels of an agreement with the United States that Japan's government-run National Space Development Agency (NASDA) will launch only research satellites, and that all commeropened up to competitive, including foreign, bidding (see Nature 344, 578; 12 April 1990).

Although no official statement has been made, it seems likely that the reason for transferring responsibility for $\mathrm{H}$-II production from NASDA to the private launches using the H-II. But there are many barriers to the establishment of such a commercial launch operation.

The new company is being set up with an initial target investment of $¥ 480$ million ( $\$ 3$ million) by more than 70 companies, including Mitsubishi Heavy Industries, Ishikawajima-Harima Heavy Industries, Kawasaki Heavy Industries, Nissan, NEC, Toshiba, Fujitsu, Mitsubishi Electric, Japan Aviation Electronics Industry and a number of insurance companies interested in insuring satellites.

At present, the Science and Technology Agency (STA), to which NASDA is affiliated, orders rockets one at a time from private industry, which means that even prime contractors such as Mitsubishi Heavy Industries and Nissan cannot risk setting up a production line and building up large inventories of spare parts. NASDA rockets are thus much more expensive than their equivalents in the United States and Europe.

After two test launches of the H-II by NASDA in 1993, the new company will take over ordering, production and delivery of the rockets. Production costs are expected to be considerably reduced and, as pointed out in a NASDA document describing the new company, the next logical step after reducing costs would be for the company to take over launch of the rockets. But "at present" that is not a goal, according to the document.

Katsuo Yonezawa of NASDA's international affairs division says there are many legal and political hurdles to overcome before a commercial launch business can be established in Japan. The law governing NASDA's operations limits the agency to research and development, and was written that way because of an agreement with the United States for the transfer of US rocket technology to cial satellite building and launching will be sector is ultimately to allow commercial rockets were based entirely on US rocket technology.

The recent dispute with the United States over satellites arose because Japan tried to claim that next-generation communication, broadcasting and meteorological satellites which NASDA planned to launch in the mid-1990s would be for research and development purposes only. But under the new agreement, Japan accepts that they are "commercial" and thus under the NASDA law they cannot be launched by NASDA.

The law would have to be rewritten if the new private company were to use NASDA's launch facilities for commercial purposes. But Yonezawa says there are no moves afoot to change the law, particularly under the present political climate where the United States has put strong pressure on Japan to open up its commercial satellite market to foreign countries.

Another barrier has been erected by the fishermen of Tanegashima island where NASDA's launch centre is located. Under an agreement with the fishermen, NASDA is limited to two launches a year during two 45-day periods in summer and winter. In return, the fishermen get several million dollars compensation every year for supposed damage to tuna fisheries.

The new launch facility for the H-II at Tanegashima will be capable of launching four rockets during the two 45-day periods because one rocket can be kept on standby while another is on the launch pad. But the two extra launches will require renegotiations with the fishermen, Yonezawa says.

But even four launches a year will probably not be enough for a commercial operation. Dieter Brand of the Tokyo office of Arianespace, the world's first commercial rocket launching company, says that about eight launches per year carrying two satellites are needed for a successful commercial operation (Arianespace is capable of ten such launches a year).

Even if all these hurdles are overcome, there is still likely to be strong opposition from the United States. By 1994, the Japanese government will have spent $¥ 237,000$ million $(\$ 1,500$ million $)$ on development of the $\mathrm{H}$-II and another $¥ 96,000$ million on new launch facilities for the rocket.

Any attempt to hand these assets over to a private company competing in the international market for commercial satellite launches is likely to raise complaints from the United States that the Japanese government is unfairly subsidizing a commercial operation.

David Swinbanks
NASDA - NASDA's early $\mathrm{N}$-series

\section{Another strike}

\section{London}

Researchers at the Natural History Museum in London went on a second oneday strike last Friday (11 May) over the museum's controversial corporate plan (see Nature 345, 99; 10 May 1990). The researchers, who belong to the Institution of Professionals, Managers and Specialists (IPMS) were protesting about the loss of one in six research posts under the plan. The IPMS claims that it was not consulted during the plan's draft stages. This second strike follows the failure of discussions last Wednesday (9 May) between IPMS representatives, the museum's director, Neil Chalmers, and the museum's board of trustees, about how the plan might be amended to take more account of the researchers' interests.

In the meantime, Sir Hugh Leggatt, a member of the 14-strong Museums and Galleries' Commission (MGC) had received so many letters expressing concern at the NHM's corporate plan that he went to the museum to assess the situation for himself. The MGC is an independent body of distinguished academics that advises both government and museums on matters of policy. Although Leggatt notes "a very serious sense of grievance on the Union side", he recognizes the constraints imposed on management faced with a decrease in core funding: "the basic problem is - in one word - money".

- See also Correspondence, page 198.

Henry Gee

\section{Correction: Professor Nicolae Simionescu}

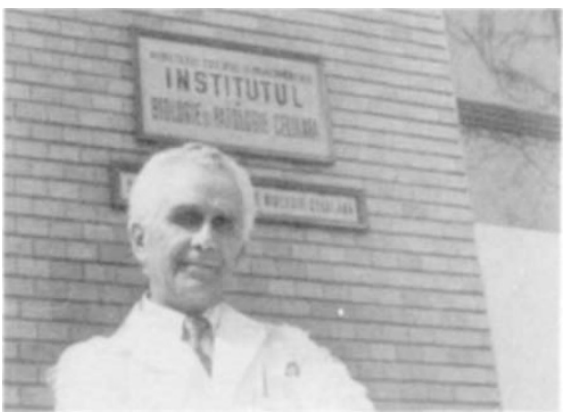

INEXCUSABLY, for an international journal on an international subject, the caption beneath the photograph of Professor Nicolae Simionescu of the Institute of Cellular Biology and Pathology in Bucharest (Nature 344, 614; 1990) included a misleading English catchphrase. In Britain, to "help the police with the inquiries" is the euphemism describing those suspected of crimes who are questioned but who have not yet been charged. In Romania, to "help the Securitate with their inquiries" understandably means something different. Nature apologizes to Professor Simionescu and his colleagues for this unfortunate phrase. 